\title{
PENGARUH GAYA KEPEMIMPINAN, BUDAYA ORGANISASI DAN MOTIVASI KERJA TERHADAP KINERJA PEGAWAI PEMERINTAH DAERAH PROVINSI GORONTALO
}

\author{
DINARWATI.CH \\ Widyaiswara PBSDM Kemendagri Regional Makassar \\ E-mail : Dinarwati24@yahoo.com
}

\begin{abstract}
ABSTRAK
Penelitian ini bertujuan untuk mengetahui pengaruh gaya kepemimpinan, budaya organisasi dan motivasi kerja terhadap kinerja pegawai Pemerintah Daerah Provinsi Gorontalo. Sampel dalam penelitian ini sebanyak 110 pegawai pada Pemerintah Daerah Provinsi Gorontalo. Teknik pengumpulan data dilakukan melalui wawancara dengan menggunakan model kuesioner serta teknik obervasi. Teknik analisis data menggunakan Structural Equation Modeling (SEM) dengan menggunakan program Analysis of Moment Structures (AMOS) versi 4.00. Hasil penelitian ini menunjukkan bahwa gaya kepemimpinan berpengaruh positif dan signifikan terhadap budaya organisasi dan motivasi kerja namun tidak berpengaruh signifikan terhadap kinerja pegawai. Budaya organisasi berpengaruh positif dan signifikan terhadap motivasi kerja namun tidak berpengaruh signifikan terhadap kinerja pegawai, sedangkan motivasi kerja berpengaruh positif dan signifikan terhadap kinerja Pegawai pada Pemerintah Daerah Provinsi Gorontalo.
\end{abstract}

Kata Kunci: gaya kepemimpinan, budaya organisasi, motivasi kerja, kinerja pegawai

\section{THE INFLUENCE OF LEADERSHIP STYLE, ORGANIZATIONAL CULTURE, AND WORK MOTIVATION TO EMPLOYEE PERFORMANCE IN GOVERNMENT GORONTALO PROVINCE}

\begin{abstract}
This study aims to know the influence of leadership style, organizational culture, and work motivation to employee performance in Government Gorontalo Province. Sampling for this study were 110 employees at Gorontaio Provinsi. Data were collected by interview using a questionnaire models and observation techniques. To test the model established pattern of relationships, use of analytical tools that are able to simultaneously explain the relations that using Structural Equation Modeling (SEM) by using the program Analysis of Moment Structures (AMOS) version 16. The results of this study indicate that the style of leadership and a significant positive effect on organizational culture and work motivation but no significant effect on employee performance. Organizational culture and a significant positive effect on work motivation, but no significant effect on the performance of employees, while work motivation positive and significant impact on the financial performance Employee at the Office of Government Gorontalo Province
\end{abstract}

Keywords : leadership style, organizational culture, employee motivation, employee performance

\section{PENDAHULUAN}

Keberhasilan suatu organisasi sangatlah ditentukan oleh pegawai dalam menjalankan tugas sehari-hari. Setiap pegawai mempunyai perbedaan dalam banyak hal, oleh karena itu seorang pemimpin haruslah dapat mengetahui bagaimana perbedaan tersebut mempengaruhi perilaku dan kualitas kerja bawahannya. Hanya saja kenyataan menunjukkan bahwa hingga saat ini, upaya-upaya peningkatan kualitas kerja pegawai, baik secara teknis administratif maupun teknis operasional belum mampu memenuhi harapan dari pelaksanaan reformasi birokrasi tersebut. 
Kepemimpinan diartikan sebagai fundamental dan esensial dalam kelangsungan organisasi. Moeheriono (2012), kepemimpinan adalah proses oleh seseorang atau kelompok mencoba mempengaruhi tugas-tugas dan sikap orang lain terhadap sebuah akhir dari hasil yang dikehendaki untuk mencapai visi misi organisasi. Lanjut dikatakan bahwa kepemimpinan dapat dilaksanakan dan didefinisikan berdasarkan penerapannya pada pemerintahan, pendidikan, bisnis. A. Dale Timpe (2002), menyatakan bahwa kepemimpinan adalah proses mempengaruhi kegiatan orang lain menuju pada pencapaian sasaran.

Budaya organisasi merupakan bagian dari manajemen sumber daya manusia (MSDM) dan teori organisasi untuk meningkatkan kinerja staf. Robbins (2007), menyatakan bahwa budaya organisasi mengacu pada sistem makna bersama yang dianut oleh anggota yang membedakan organisasi itu dari organisasi lain.

Gibson dan Donelly (2000), menyatakan bahwa budaya organisasi adalah sebuah pola asumsi dasar yang cukup bekerja baik untuk dipertimbangkan layak. Oleh karena itu, diajarkan kepada anggota baru sebagai cara yang benar untuk mempersepsikan, berpikir dan merasa dalam hubungannya dengan masalah yang ada. Greenberg and Baron (2003), menyatakan budaya organisasi sebagai kerangka kerja kognitif yang terdiri dari sikap, nilainilai, norma perilaku, dan harapan yang diterima bersama oleh anggota organisasi.

Motivasi dapat diartikan sebagai kekuatan (energi) seseorang yang bersumber dari dalam diri individu itu sendiri maupun dari luar individu. Oleh Robbins (2007), mendefinisikan motivasi sebagai proses yang ikut menentukan intensitas, arah, dan ketekunan individu dalam usaha mencapai sasaran. Definisi yang dikemukakan Robbins ada tiga unsur kunci yaitu intensitas, arah dan berlangsung lama. Hal yang sama sebagaimana definisi yang dikemukakan oleh Asnawi Sahlan (2002), bahwa motivasi adalah konstruksi dan proses interaksi antara harapan dan kenyataan masa yang akan datang baik dalam jangka pendek, sedang ataupun panjang.

Kinerja pegawai merupakan istilah yang berasal dari Job Performance atau actual performance yakni prestasi kerja atau prestasi yang sesungguhnya yang dicapai seseorang. Mangkunegara (2004), bahwa kinerja pegawai (prestasi kerja) adalah hasil kerja secara kualitas dan kuantitas yang dicapai oleh seorang pegawai dalam melaksanakan tugasnya sesuai dengan tanggung jawab yang diberikan kepadanya.

Menurut Dessler (1998), bahwa penilaian kinerja memungkinkan bagi pimpinan dan bawahan untuk mengembangkan satu rencana untuk memperbaiki kemerosotan yang mungkin terjadi dan mendorong hal-hal yang dilakukan oleh bawahannya sedang akhir penilaian akan memberikan proses perencanaan karier bagi organisasi karena penilaian tersebut akan memberikan satu peluang yang baik untuk meninjau rencana karier seseorang.

Menurut Bernardin (1993), bahwa untuk meningkatkan kinerja pegawai pada suatu organisasi harus diperbaiki dan ditingkatkan beberapa hal yaitu knowledge, skills, abilities, attitude dan behaviors. Karena dengan hal tersebut maka ukuran keberhasilan yang dicapai seorang pegawai dalam melaksanakan kegiatannya semakin efektif, efisien dan meningkat.

Meningkatnya kinerja pegawai tidak semata-mata dipengaruhi oleh besar kecilnya tingkat gaji atau honor, melainkan juga dipengaruhi oleh faktor-faktor lain seperti gaya kepemimpinan, motivasi, budaya organisasi, fasilitasi kerja, pendidikan dan pengalaman serta lingkungan kerja. Bahkan secara khusus budaya organisasi pada pemerintahan Provinsi Gorontalo dipengaruhi pula oleh budaya (adat) dan ajaran islam yang dilandasi filosofi "Adat Besendi Syara, Syara Bersendi Kitabullah". Dengan prinsip ini masyarakat Gorontalo juga pegawai dikenal sangat ramah tapi mudah tersinggung.

Berdasarkan pada asumsi-asumsi tersebut di atas, maka tujuan penelitian ini adalah untukmengetahui pengaruh gaya kepemimpinan, budaya organisasi, dan motivasi kerja terhadap kinerja pegawai Pemerintah Daerah Provinsi Gorontalo..

Kepemimpinan adalah sikap pribadi,yang memimpin pelaksanaan aktivitas untuk mencapai tujuan yang diinginkan ( Shared Goal,Hemhiel\& Coons,1957,7)Thoha (2006:48) membedakan defenisi pemimpin dengan kepemimpinan.Dimana pimpinan adalah hak setiap 
oranguntuk menjadi pemimpin,baik memimpin dirinya sendiri,keluarga,kelompok,masyarakat atau organisasi..

Budaya organisasi adalah setiap dan semua organisasi merupakan kumpulan sejumlah manusia sebagai anggota organisasi yang saling berinteraksi.Setiap anggota organisasi menerima, menghormati dan menjalankan nilai-nilai atau norma-norma tertentu yang sama di dalam organisasi. Nilai-nilai atau norma-norma sebagai unsur budaya manusia itu hidup dan berkembang secara dinamis sesuai dengan kondisi organisasi dan menjadi kendali cara berpikir, bersikap dan berperilaku hidup bersama dalam kebersamaan sebagai sebuah organisasi. Nilai-nilai atau norma-norma itulah yang kemudian menjadi budaya organisasi.(Schein,1991). Motivasi dalam penerapan manajemen sumber daya manusia sangat diperlukan melalui konsep motivasi sumber daya manusia akan dipahami hal yang mendorong,merangsang,menyemangati atau seseorang memiliki motif untuk beraktivitas.Bisa saja wujud motivasi tersebut dari dalam diri maupun dari luar diri. Davis (2008;49) Kinerja evaluasi merupakan pendapat yang bersifat evaluative atas sifat, prilaku seseorang atau prestasi sebagai dasar untuk keputusan dan rencana pengembangan personil (Kreitner dan Kinicki, 2001:300). Sementara itu, Newstrom dan Davis (1997:173) memandang sebagai suatu proses mengevaluasi kinerja pekerja, membagi informasi dengan mereka ,dan mencari cara memperbaiki kinerjanya.

\section{METODE PENELITIAN}

Penelitian ini dilaksanakan pada 33 Satuan Kerja Perangkat Daerah (SKPD) pada Pemerintah Daerah (pemda) Provinsi Gorontalo,yang menggamabarkan fonemena variable,yakni gaya kepemimpinan, budaya organisasi, dan motivasi kerja dalam meingkatkan kinerja pegawai itu sendiri.

\section{Jenis dan Sumber Data}

Jenis data penelitian adalah kualitatif dan kuantitatif yang terdiri dari data primer dan sekunder. Data primer yaitu data yang diperoleh atau dikumpulkan oleh peneliti secara langsung dari sumber datanya. Data primer tersebut berupa hasil wawancara dengan responden dan hasil angket (kuesioner). Data sekunder yaitu data yang diperoleh atau dikumpulkan peneliti dari berbagai sumber yang telah ada. Data sekunder tersebut antara lain: majalah, bulletin, jurnal, hasil penelitian terdahulu dan berbagai dokumentasi dari instansi pemerintah.

\section{Teknik Pengumpulan Data}

Teknik pengumpulan data primer melalui wawancara, observasi dan kuesioner. (instrumen) yang digunakan adalah observasi dan kuesioner. Sedangkan metode yang digunakan untuk memperoleh data sekunder melalui teknik dokumentasi yaitu mengamati data dari dokumen-dokumen yang ada kaitannya dengan objek penelitian antara lain: bukubuku, majalah, peraturan-peraturan, dan catatan harian.

\section{Populasi dan Sampel}

Populasi dalam penelitian ini adalah pegawai pada Pemerintah Daerah Provinsi Gorontalo sebanyak 2.657 orang. Sampel penelitian adalah pegawai dan pejabat struktural Pemerintah Daerah Provinsi Gorontalo dengan penentuan jumlah sampel menggunakan formulasi Slovin sehingga ditetapkan jumlah sampel 110 pegawai.

\section{Analisis Data}

Teknik analisis data yang digunakan dalam menjelaskan fenomena dalam penelitian ini adalah teknik analisis statistic deskriptif dan analisis Structural Equation Modeling (SEM).

\section{HASIL DAN PEMBAHASAN}

Telah dilakukan penelitian kuantitatif dan kuantitatifuntuk mengetahui pengaruh gaya kepemimpinan, budaya organisasi, dan motivasi kerja terhadap kinerja pegawai Pemerintah Daerah Provinsi Gorontalo. Hasil penelitian menemukan bahwa gaya kepemimpinan 
berpengaruh positif signifikan terhadap budaya organisasi. Ohio dalam Gibson (1985) menyatakan bahwa ada 2 faktor dalam menganalisis Gaya Kepemimpinan, pertama faktor inisiasi, seperti perilaku pemimpin di dalam menentukan hubungan kerja antara pimpinan dengan pegawainya, menentukan dan menjelaskan pola serta saluran komunikasi dan memberi penjelasan tentang kinerja pegawai. Kedua faktor konsiderasi yang menjelaskan kesetiakawanan, bersahabat, rasa hormat, saling mempercayai, dan kehangatan di dalam hubungan kerja antara pemimpin dengan para pegawainya. Hal ini berarti bahwa budaya organisasi yang terbentuk dari kesetiakawanan, bersahabat, saling percaya, dan rasa hormat sangat dipengaruhi oleh gaya kepemimpinan, sehingga pada akhirnya akan berdampak pada peningkatan motivasi kerja pegawai.

Gaya Kepemimpinan berpengaruh positif dan signifikan terhadap Motivasi Kerja pada Pemerintah Daerah Provinsi Gorontalo. Menurut Amar (2004) sebagai pemimpin dalam organisasi perlu memperhatikan Gaya Kepemimpinan yang digunakannya dalam memotivasi dan mengarahkan para pegawai agar mereka dapat berprestasi kerja yang lebih baik. Gaya kepemimpinan ini dapat menjadikan pegawai akan termotivasi untuk berkarier dan keinginan untuk maju serta berkembang. Gaya kepemimpinan seorang pemimpin akan sangat mempengaruhi kondisi kerja pegawai, dimana akan berhubungan dengan bagaimana pegawai menerima suatu gaya kepemimpinan, senang atau tidak, suka atau tidak yang pada akhirnya pegawai bisa termotivasi untuk melakukan pekerjaannya dengan baik. Oleh karena itu pada Pemerintah Daerah Provinsi Gorontalo dibutuhkan pemimpin yang selain mempunyai kemampuan pribadi, juga mampu membaca keadaan pegawainya serta lingkungan kerjanya. Dalam hal ini kematangan pegawai berkaitan langsung dengan gaya kepemimpinan yang tepat untuk diterapkan, agar pemimpin memperoleh ketaatan atau pengaruh yang memadai. Untuk itu pemimpin harus mampu menciptakan suasana kerja yang mendukung para pegawai untuk selalu berprestasi.

Gaya kepemimpinan berpengaruh positif signifikan terhadap kinerja pegawai pada Pemerintah Daerah Provinsi Gorontalo. Siagian (1994), yang menyatakan bahwa tidak semua gaya kepemimpinan yang diterapkan dalam menjalankan aktifitasnya mempunyai pengaruh yang sama terhadap pencapaian tujuan organisasi, dalam hal ini penggunaan gaya kepemimpinan yang tidak tepat justru akan menurunkan kinerja pegawai. Pengaruh gaya kepemimpinan pada Pemerintah Daerah Provinsi Gorontalo terhadap kinerja juga menunjukkan bahwa gaya kepemimpinan yang dipergunakan oleh pimpinan belum sesuai. Partisipasi pegawai dalam memberikan kontribusinya pada organisasi perlu terus dioptimalkan untuk meningkatkan kinerja pegawai.

Temuan hasil penelitian ini dibandingkan dengan penelitian sebelumnya berbeda pada obyek penelitian ini adalah usaha pada Pemerintah Daerah Provinsi Gorontalo sangat terkait dengan ketelitian dan ketrampilan yang memerlukan suasana emosi yang cukup baik, dan tantangan untuk memberikan hasil yang berkualitas. Selain itu bawahan dilibatkan dalam pengambilan keputusan. Oleh karena itu pimpinan seharusnya melibatkan pegawai dalam proses, dengan cara melatih, membimbing pegawai secara terus menerus sehingga dapat hasil kerja yang berkualitas. Disamping itu pimpinan melakukan work studi terhadap cara kerja dari pegawai yang merupakan pedoman untuk memotivasi pegawai dalam menaikkan hasil kerjanya.

Pimpinan pada Pemerintah Daerah Provinsi Gorontalo bila menggunakan gaya kepemimpinan otokrasi dan gaya kecepatan (dua dimensi yang dominan dalam gaya kepemimpinan maka sulit bagi bawahan menerima kondisi yang demikian karena secara psikologis atau emosional mereka tertekan karena tuntutan harus taat pada peraturan dan spesialisasi yang sempit, rasional sehingga pegawai merasa mereka merupakan suatu bagian didalam organisasi, sehingga mempunyai tempat pada perasaan dan kemampuannya untuk berkreasi. Penggunaan gaya kepemimpinan oleh seseorang agar berhasil secara optimal, yaitu dengan cara melakukan work study terhadap para pegawai. Apa yang mereka perlukan dan bagaimana meningkatkan cara kerja mereka seoptimal mungkin sehingga antara pimpinan dan 
pegawai diperoleh keberhasilan bersama, untuk itu gaya kepemimpinan yang mampu mengkombinasikan antara gaya paksaan, gaya otokrasi, gaya afiliasi, gaya kecepatan dan gaya pelatih secara profesional dan proporsional.

Budaya organisasi berpengaruh positif signifikan terhadap motivasi kerja. Pada level Artifak adalah hal-hal yang dilihat, didengar, dan dirasa kalau seseorang berhubungan dengan sebuah kelompok baru dengan budaya yang tidak dikenalnya, bahkan tingkah laku pegawai. Nilai-nilai yang mendukung adalah hal-hal yang berharga untuk dikerjakan, atau alasan mengerjakan apa yang kita kerjakan. Schein (1992), mengatakan bahwa budaya sebagian besar organisasi dapat melacak nilai-nilai yang didukung kembali ke penemu budaya. Asumsi dasar adalah keyakinan yang dianggap sudah ada oleh anggota organisasi. Budaya menetapkan "cara yang tepat untuk melakukan sesuatu" di sebuah organisasi. Sering kali lewat asumsi yang tidak diucapkan, dan kadang-kadang tidak disadari. Budaya organisasi pada tingkat analisis artifak bersifat kasat mata yang dapat dilihat dari lingkungan fisik organisasi, arsitektur, teknologi, tata letak kantor, cara berpakaian, pola perilaku yang dapat dilihat atau didengar, serta dokumen-dokumen publik seperti anggaran dasar, materi orientasi pegawai, dan cerita, hal-hal ini mampu memotivasi pegawai untuk meningkatkan motivasi kerja pegawai pada Pemerintah Daerah Provinsi Gorontalo.

Budaya organisasi merupakan pola asumsi dasar dan bentukan, temuan atau pengembangan oleh suatu kelompok orang yang telah bekerja cukup baik untuk mengatasi masalah-masalah adaptasi eksternal maupun internal, sehingga perlu diajarkan pula kepada pegawai baru sebagai ears yang benar dalam memandang, berpikir dan merasa tentang masalah-masalah yang dihadapi, pada akhirnya akan memotivasi pegawai agar mau bekerjasama secara produktif berhasil mencapai dan mewujudkan tujuan yang telah ditentukan.

Budaya organisasi pada dasarnya mewakili norma-norma perilaku yang diikuti oleh para anggota organisasi, termasuk bagi mereka yang ada dalam hirarki organisasi, sehingga budaya organisasi tersebut sangat penting peranannya dalam mendukung terciptanya suatu organisasi yang efektif. Budaya organisasi juga dapat berperan serta dalam menciptakan jati diri, mengembangkan keikatan pribadi dengan organisasi sekaligus menyediakan pedoman perilaku kerja pegawai.

Budaya organisasi juga mencerminkan sifat-sifat atau ciri-ciri yang terdapat dalam lingkungan kerja dan muncul karena adanya kegiatan dalam organisasi, yang dilakukan secara sadar atau tidak, dan dianggap mempengaruhi perilaku, sehingga budaya yang ada pada perusahaan dapat dipandang sebagai kepribadian organisasi. Hal ini berarti bahwa dalam meningkatkan motivasi kerja sangat ditentukan oleh budaya organisasi yaitu kesetiakawanan, bersahabat saling mempercayai dan rasa hormat sehingga dapat meningkatkan motivasi kerja pegawai. Budaya organisasi berpengaruh positif signifikan terhadap kinerja pegawai tidak terbukti atau tidak didukung dengan fakta. Hasil penelitian ini tidak mendukung peneliti terdahulu yang menemukan bahwa budaya perusahaan berpengaruh terhadap kinerja individu, kelompok dan organisasi, begitu besar pengaruh budaya organisasi sehingga dapat dikatakan melebihi pengaruh faktor-faktor lain.

Budaya organisasi berpengaruh positif dan tidak signifikan terhadap kinerja pegawai disebabkan karena inovasi dan pengambilan resiko, perhatian dan keindahan, orientasi hasil, tim dan tugas, tidak memberikan kontribusi yang optimal terhadap budaya organisasi sehingga juga tidak berdampak pada kinerja pegawai. Oleh karena itu pimpinan organisasi perlu memperhatikan nilai-nilai budaya dalam mendukung peningkatan kinerja pegawai, selanjutnya juga perlu diamati dengan lebih detail lagi variabel lain yang kemungkinan lebih berpengaruh terhadap kinerja pegawai seperti kompetensi dan kepuasan kerja pegawai.

Budaya organisasi adalah komponen yang sangat penting dalam meningkatkan kinerja pegawai namun demikian agar kinerja karyawan meningkat maka harus ditingkatkan pula motivasi kerjanya. Budaya organisasi pada sisi internal pegawai akan memberikan sugesti kepada semua perilaku yang diusulkan oleh organisasi agar dapat dikerjakan, penyelesaian 
yang sukses, dan akibatnya akan memberikan konstribusi pada pegawai itu sendiri. Akibatnya pegawai akan memiliki kepercayaan pada diri sendiri, kemandirian diri dan mengagumi dirinya sendiri. Sifat-sifat ini akan dapat meningkatkan harapan pegawai agar kinerjanya semakin meningkat. Hasil penelitian ini menunjukkan inovasi \& pengambilan resiko, perhatian dan keindahan, orientasi hasil, orientasi tim, orientasi tugas, keagresifan, kemantapan tidak akan meningkatkan kinerja pegawai bila tidak didukung oleh adanya motivasi kerja.

Motivasi kerja mempunyai pengaruh yang tidak signifikan terhadap kinerja pegawai pada Pemerintah Daerah Provinsi Gorontalo. Penelitian ini juga menunjukkan adanya pengaruh negatif antara motivasi kerja terhadap kinerja pegawai yang ditandai dengan koefisien jalur yang negatif. Menurut Wagimin (2001). Upaya yang dilakukan oleh perusahaan untuk meningkatkan kinerja pegawai tersebut adalah dengan memperhatikan faktor-faktor yang memotivasi antara lain: peningkatan gaji dan tunjangan, keselamatan dan keamanan, jaminan kerja tidak dipecat, pujian, perhatian pimpinan, serta penghargaan, sedangkan faktor-faktor kemampuan kerja misalnya mengembangkan kemampuan menganalisis, membaca dan mendengar, serta menggunakan logika. Dengan memperhatikan faktor-faktor tersebut pegawai diharapkan lebih giat dalam melaksanakan tugas dan tanggung jawabnya. Oleh karena itu pada Pemerintah Daerah Provinsi Gorontalo sangat diperlukan kesempatan berkarier, kesempatan maju dan untuk berkembang bagi pegawai agar kinerja pegawai bisa menjadi semakin baik.

Motivasi merupakan daya pendorong yang menyebabkan pegawai dapat bekerja dengan giat, karena dengan motivasi akan menentukan prestasi seseorang. Motivasi yang diberikan pimpinan kepada pegawainya haruslah tepat, karena pemberian motivasi akan mempengaruhi kinerja pegawai. Sehingga menjadi salah satu tugas dari seorang pemimpin untuk bisa memberikan motivasi (dorongan) kepada pegawainya agar bisa bekerja sesuai pengarahan yang diberikan, sehingga dari beberapa pendapat di atas dapat disimpulkan bahwa motivasi yang diberikan pada pegawai akan mempengaruhi perilaku mereka dalam bekerja agar lebih tinggi guna pemenuhan suatu harapan yaitu pemenuhan akan prestasi dalam bekerja sebab tercapainya kinerja pegawai yang tinggi didorong oleh motivasi yang tinggi pula.

\section{PENUTUP}

\section{Kesimpulan}

Berdasarkan hasil penelitian dan pembahasan yang telah diuraikan di atas, maka dapat diambil kesimpulan yaitu :(1) Gaya kepemimpinan adalah gaya yang digunakan untuk mempengaruhi, mengatur dan mengkoordinasikan pegawai dalam rangka pencapaian tujuan yang efektif; (2) Gaya kepemimpinan berpengaruh positif dan signifikan terhadap budaya organisasi; (3) Gaya kepemimpinan berpengaruh positif dan signifikan terhadap motivasi kerja pegawai; (4) Budaya organisasi berpengaruh positif dan signifikan terhadap motivasi; (5) Budaya organisasi mempunyai pengaruh positif dan tidak signifikan terhadap kinerja pegawai; (6) Motivasi berpengaruh negatif dan tidak signifikan terhadap kinerja pegawai organisasi.

\section{Saran}

Disarankan agar menerapkan gaya kepemimpinan otokrasi dimana pegawai selalu ada arahan dan motivasi serta perhatian pemimpin dalam menjalankan aktivitas organisasi lebih memiliki keselarasan terhadap budaya organisasi dan motivasi kerja pegawai. Sebaiknya dilakukan pelatihan kepemimpinan dan budaya organisasi yang berorientasi pada pembentukan pemimpin dan pegawai yang memiliki kompetensi, agama, dan berdedikasi tinggi terhadap organisasi baik organisasi pemerintah maupun swasta.

Berdasarkan hasil penelitian menunjukkan bahwa baik metode jurnal maupun metode analisis secara statistik terbukti dengan menerapkan gaya kepemimpinan otokrasi, dimana pegawai selalu ada arahan dan motivasi serta perhatian pemimpin dalam menjalankan aktivitas 
organisasi yang keselarasan dengan budaya organisasi dan motivasi kerja pegawai. Dengan demikian ada beberapa rekomendasi terhadap kinerja pegawai sebagai berikut :

a. Gaya kepemimpinan otokrasi dan gaya kecepatan (dua dimensi yang dominan dalam gaya kepemimpinan maka sulit bagi bawahan menerima kondisi yang demikian karena secara psikologis atau emosional mereka tertekan karena tuntutan harus taat pada peraturan dan spesialisasi yang sempit, rasional sehingga pegawai merasa mereka merupakan suatu bagian didalam organisasi.

b. Untuk mengukur sejauh mana pengaruh gaya kepemimpinan,budaya organisasi dan motivasi terhadap kinerja diperlukan pengukuran kinerja yang berbasis Kompetensi bagi organisasi untuk menjalankan Visi-Misi.

\section{DAFTAR PUSTAKA}

Amar. 2004. Pemimpin Bisnis Sebagai Pemimpin Budaya,Manajemen No. 99 Mei-Juni, 2004

AsnawiSahlan. 2002. TeoriMotivasi (Dalam Pendekatan Psikologi Industri dan Organisasi).Cetakan Pertama.Jakarta: Studia Press.

Bernandin, H. Johnand Joyce E, A. Russei. 1993. Human Resources Management.Singapore: McGraw Hill Inc.

Dessler, Gary. 1998. Manajemen Sumber Daya Manusia.Edisibahasa Indonesia. Jilid 2. Jakarta: PT. Prehalindo.

Gibson, James L. 1985.Organizations, Behavior-Structure and Process.Plano Texas: Business Publication Inc.

Gibson, James L., M. John Ivancevich, and H. James Donnely. 2000.Organisasi, Perilaku Struktur Proses.Jilid 1. EdisiKelima. Terjemahan. Jakarta: PenerbitErlangga.

Greenberg A., dan Michael Baron J. 2003. Behavior in Organization: Understanding and Managing The Human Side of Work. 3P Edition.New Jersy: Pretince Hall Inc.Upper Saddle River.

Mangkunegara, Anwar P. 2004. Manajemen Sumber Daya Manusia.Edisi Keempat. Yogyakarta: Gajah Mada University Press.

Moeheriono. 2012. PengukuranKinerjaBerbasisKompetensi.Jakarta: Rajawali.

Robbins, Stephen,P.2007. Perilaku Organisasi. Terjemahan Alih Bahasa Benyamin Molan.EdisiLengkap. Jakarta: PT.Indeks.

Schein,. H. Edgar. 1992. An Organizational Culture And Leadership. San Fransisco: Jossey Bass Publisher.

Siagian, Sondang, P. 1994. Teori Motivasi dan Aplikasinya.Jakarta: Penerbit PT. Rineka Cipta.

Timpe, Dale, A. 2002. Kepemimpinan (Leadership). Jakarta: PT Elex Media Komputindo

Wagimin Ign. 2001. Pengaruh Motivasi dan Kemampuan Terhadap Prestasi Kerja. Tesis. Malang: Universitas Brawijaya. 